\title{
Memória de trabalho em crianças avaliada pela Tarefa de Brown-Peterson****
}

\author{
Working memory in children assessed by the Brown-Peterson Task
}

\author{
Ivanilde Aparecida Vaz * \\ Priscila Maria Cordeiro* \\ Elizeu Coutinho de Macedo** \\ Katerina Lukasova***
}

*Graduanda em Psicologia. Endereço para correspondência: Laboratório de Psicologia - Av. Padre Olivetano, 691 São Paulo - SP - CEP 03648-000 (ivyunicsul@gmail.com).

**Psicólogo. Doutor em Psicologia Experimental pelo Instituto de Pscicologia da Universidade de São Paulo (USP). Coordenador do Núcleo de Neurociências do Comportamento do Programa de Pós-Graduação em Distúrbios do Desenvolvimento da Universidade Presbiteriana Mackenzie de São Paulo.

***Psicóloga. Mestre em Distúrbios do Desenvolvimento pela

Universidade Presbiteriana Mackenzie. Professora do Curso de Psicologia da Universidade Cruzeiro do Sul de São Paulo.

****Trabalho Realizado no Centro da Criança e Adolescente - São Paulo Brasil.

Artigo Original de Pesquisa

Artigo Submetido a Avaliação por Pares

Conflito de Interesse: não

Recebido em 08.06.2009.

Revisado em 22.12.2009; 24.02.2010; 07.05.2010.

Aceito para Publicação em 07.05.2010.

\section{Abstract}

Background: the working memory is a cognitive skill that contributes to adequate development of language and to the acquisition of reading and writing. A consistent evaluation of the working memory in pre-school and basic school children demonstrates to be important for the early identification of possible learning impairments. Aim: to evaluate the development of working memory along the first school grades of basic education and to verify the applicability of the Brown-Peterson Task in the assessment of this function in children. Method: 103 children, 63 males, with the mean age of 9.75, recruited from 1st to 6th grades of basic school participated in the study. The children were assessed with the BrownPeterson Task, the Digit Span forward and the Digit Span Backward. The results were compared for the variables of gender, age and grade. Results: the score on the Brown-Peterson Task increased along the school grades and age groups. A linear decrease in scoring was observed in longer interference intervals. A positive correlation was found between the Brown-Peterson Task and the Digit Span, yet the BrownPeterson Task proved to better differentiate school grades. Conclusion: the study confirmed that working memory development continues during the basic education years, indicating late maturation of related brain areas. The Brown-Peterson Task proved to be an adequate tool for the assessment of working memory in children.

Key Words: Memory; Outcome Assessment; Basic Education.

\section{Resumo}

Tema: a memória de trabalho é uma habilidade cognitiva que contribui para o adequado desenvolvimento da linguagem e aquisição das habilidades de leitura e escrita. Uma avaliação consistente de memória de trabalho em crianças pré-escolares e escolares faz-se importante para identificação precoce das possíveis dificuldades de aprendizagem. Objetivo: o presente estudo teve como objetivo avaliar o desenvolvimento da memória de trabalho ao longo das séries iniciais do ensino fundamental e verificar a adequação da Tarefa de Brown Peterson na avaliação desta função em crianças. Método: participaram do estudo 103 crianças, com a idade média de 9,75 anos, da primeira à sexta série do ensino fundamental. Entre os participantes, 63 eram do sexo masculino. As crianças foram avaliadas segundo a Tarefa de Brown Peterson, Dígitos Ordem Direta e Dígitos Ordem Inversa. O desempenho foi comparado em função das variáveis: sexo; idade e série escolar. Resultados: o desempenho na Tarefa de Brown Peterson apresentou função crescente ao longo das séries e faixas etárias. O aumento no tempo de interferência produziu diminuição linear na pontuação em todas as séries. Correlações positivas foram encontradas entre o desempenho na Tarefa de Brown Peterson e Dígitos, sendo que Tarefa de Brown Peterson se mostrou mais sensível para diferenciar as séries. Conclusão: o estudo confirmou que a maturação da memória de trabalho continua ao longo do ensino fundamental, indicando maturação tardia das áreas cerebrais relacionadas. A Tarefa de Brown Peterson se mostrou um instrumento adequado para a avaliação de memória de trabalho em crianças.

Palavras-Chave: Memória; Avaliação de Desempenho; Ensino Fundamental. 


\section{Introduction}

According to the model of Baddeley and Hitch, working memory is responsible for temporary maintenance of information in short term storage and for establishing connections with incoming information1,2. One of the subsystems described by that model is the phonological loop in which acoustic or speech-based information can be held active for a brief period of time3,4. The development of capacity to maintain acoustic information in working memory in children has been assessed and a correlation with school achievement5, reading skills6 and age7 has been reported. Working memory skills show a significantly higher improvement in first grade students as compared to preschool children6,8. In Brazil, there are currently few instruments for working memory assessment. Most frequently, the Wechsler Digit Span test9 and the non-words repetition test are used for working memory assessment in children6,10. These tests evaluate the capacity of short term information retention served by the sound reverberation on the phonological loop1112. The Brown-Peterson task, already used with the Brazilian elderly population13, assesses a short term memory capacity while reverberation is suppressed. The purposes of the present study were to analyze the working memory abilities of children from 1st to 6th grade in order to trace the development of short term memory along the initial elementary education and to verify the applicability of the Brown-Peterson task in the assessment of memory skills of children. The following tests were administered: the Brown-Peterson task parts I and II, Forward and Backward Digit Span. The scores were compared according to gender, age and grade.

\section{Method}

Participants

A total of 103 children (63 boys) with mean age of 9.75 years $(\mathrm{SD}=1.98$ years) recruited from 1 st to 6th grade of elementary school participated in the study. All participants were students at Child and Adolescent Center in Sao Paulo, Brazil. No child with sensorial and motor disabilities was included.
Table 1 shows the distribution of participants according to school grade, mean age and gender.

\section{IInstruments}

Each participant was individually assessed with the Brown-Peterson task children `s version 11 and the Forward and Backward Digit Span subtests from the Wechsler Intelligence Scale for Children9. The Brown-Peterson task is composed by twenty test items of different consonants trigrams with low phonological similarity. The test is divided in two parts: part I contains trigrams for immediate recall and part II contains 15 trials for recall after an interference task. In the immediate recall (part I), the participant is requested to listen carefully to a consonant trigram verbally presented in a rate of one letter per second and to recall it immediately after the presentation. Five different trials are presented. In the interference task (part II), the participant is requested to recall the consonant trigram only after an interval delay, during which the child counts backward starting from a random number of two digits presented by the examiner immediately after the trigram. At the end of the interval delay of 3, 9 or 18 seconds, the child is asked to recall the trigram. For each time delay, there are five trials in random order. The total score sums up to 60 points, being added one point for each letter correctly recalled.

In the Forward Digit Span, the child is asked to listen to increasing strings of digits and to immediately recall them. In the Backward Digit Span, the recall is done in reverse sequence. The score is the total number of correct recalls.

\section{Procedures}

The study was initially approved by the Ethics Committee of Universidade Cruzeiro do Sul under protocol number 008/2008. Participation in the study was voluntary and legal representative of each child signed a Consent Form. Participants underwent two separate testing sessions of 20 minutes each. The sessions took place from May to June of 2008 at the Child and Adolescent`s Center located in São Paulo. 
TABLE 1. Distribution of participants according to school grade, mean age and gender.

\begin{tabular}{cccccccc}
\hline Grade & $1^{\text {st }}$ & $2^{\text {nd }}$ & $3^{\text {rd }}$ & $4^{\text {th }}$ & $5^{\text {th }}$ & $6^{\text {th }}$ & Total \\
\hline Age & 6.89 & 7.72 & 8.72 & 9.90 & 10.94 & 11.81 & 9.43 \\
$S D$ & $(0.93)$ & $(0.75)$ & $(0.57)$ & $(0.71)$ & $(0.43)$ & $(1.25)$ & $(1.66)$ \\
Males & 4 & 7 & 15 & 21 & 12 & 4 & 63 \\
\hline Total & 9 & 18 & 18 & 30 & 17 & 11 & 103 \\
\hline
\end{tabular}

\section{Results}

The total score in the Brown-Peterson task was analyzed through ANOVAs for gender, age and school grade. There was a significant group effect for age $(F[7,95]=2.814 ; \mathrm{p}<0.01)$, grade $(\mathrm{F}[5,97]=4.854 ; \mathrm{p}$ $<0,01)$ but not for gender $(F[1,101]=0.935 ; \mathrm{p}<0.05)$. For the age variable, the descriptive mean scores were as follows: 6 years $\mathrm{M}=31.33(\mathrm{SD}=3.51)$; 7 years $\mathrm{M}=$ $34.50(\mathrm{SD}=7.69) ; 8$ years $\mathrm{M}=35.94(\mathrm{SD}=7.51) ; 9$ years $\mathrm{M}=36.53(\mathrm{SD}=7.15)$; 10 years $\mathrm{M}=40.50(\mathrm{SD}=$ 7.90); 11 years $\mathrm{M}=37.58(\mathrm{SD}=5.82)$ and 12 years $\mathrm{M}=$ 44.00 (SD = 7.96).

Further analyses are described only for the school grade variable since it presented the highest main effect. Post hoc analysis indicated improvement on Brown-Peterson score along the grades. Children in 6th grade scored significantly higher than those in 5th, 4th, 3rd, 2nd and 1st grade. ANOVAs were run for the score on Brown-Peterson part I and II. In part I, participants performed immediate recall while in part II, the recall was done after interference task. No effect was found for part $\mathrm{I}(\mathrm{F}[5,97]=1.157 ; \mathrm{p}>0,05)$ due to near ceiling performance in all grades indicating that immediate recall of three letters is an easy task even for 1st grade students. In part II, main effect was found for grade $(F[5,97]=4.800 ; p<0.001)$. Post hoc analysis indicated that 6th grade children scored significantly higher in part II than all the other grades and that 1st grade students presented significantly lower scores than all other grades. Repeated measures ANOVAs of items with the same interval delay of 3,9 and 18 seconds showed main effect for time $(F[1,97]=71.507$; $p<$ 0.0001 ) but no interaction of time with school grade $(\mathrm{F}[5,97]=1.416 ; \mathrm{p}>0.05)$. The results indicate a constant score decrease after longer delays in children of all grades. The mean scores and standard deviations are presented in Table 2.

ANOVAs revealed significant among grades score difference in Backward Digit Span ( $F[5,97]=2.398 ; \mathrm{p}<$ 0.05) but not in Forward Digit Span (F[5,97] = 1.786; $\mathrm{p}$ $>0.05)$. Post hoc analysis indicated poorer performance in 1st grade as compared to the children in 2nd, 3rd, 4th, 5th and 6th grade. The mean scores are displayed in Figure 1.

Pearson correlation was calculated for Brown-Peterson task part I, part II, Forward and Backward Digit Span. Apositive correlation was found between part II and Forward Digit $(\mathrm{r}=0.402 ; \mathrm{p}<0.001)$, part II and Backward Digit Span ( $(\mathrm{r}=0.356 ; \mathrm{p}<0.01)$, and Forward and Backward Digit Span ( $r=0.348$; $p<$ 0.01). 
TABLE 2. Mean scores on Brown-Peterson task for grades and interval delays of 3, 9 and 18 seconds. The mean scores and standard deviation are reported.

\begin{tabular}{llllllllll}
\hline Grade & $\mathrm{N}$ & $\mathrm{M}$ & $S D$ & 3 seconds & $S D$ & 9 seconds & $S D$ & 18 seconds & $S D$ \\
\hline 1 & 9 & 29.67 & 5.00 & 5.89 & 2.80 & 5.67 & 2.83 & 3.44 & 2.07 \\
2 & 18 & 36.22 & 6.26 & 9.67 & 2.95 & 7.06 & 2.04 & 4.72 & 2.85 \\
3 & 18 & 37.00 & 7.03 & 9.17 & 2.85 & 7.50 & 2.73 & 5.56 & 3.17 \\
4 & 30 & 39.73 & 8.35 & 10.77 & 2.58 & 7.53 & 3.46 & 6.83 & 3.51 \\
5 & 17 & 38.12 & 5.71 & 10.06 & 2.70 & 6.94 & 2.61 & 6.29 & 2.85 \\
6 & 11 & 44.18 & 7.68 & 11.73 & 3.07 & 10.00 & 2.90 & 7.45 & 3.08 \\
\hline \multirow{2}{*}{ Total } & 103 & 37.97 & 7.70 & 9.85 & 3.08 & 7.45 & 2.99 & 5.92 & 3.23 \\
\hline
\end{tabular}

FIGURE 1. Mean scores in Backward Digit Span for $1^{\text {st }}$ to $6^{\text {th }}$ grade.

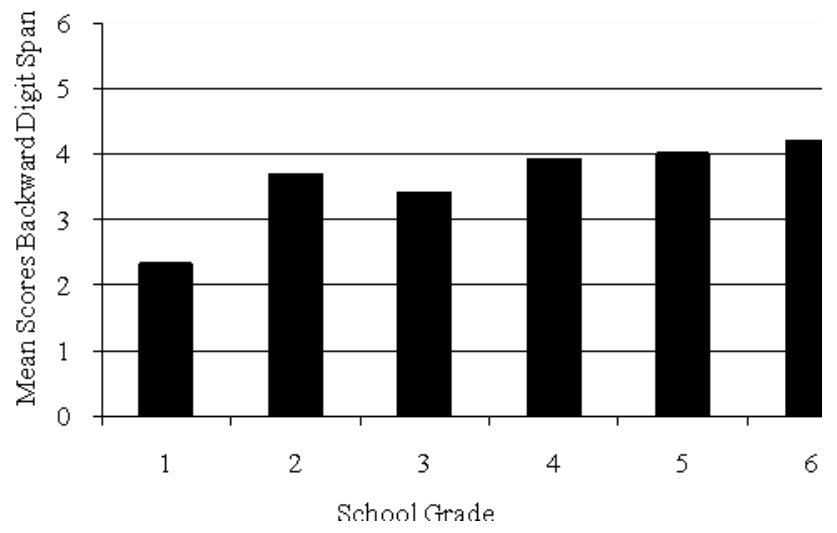

\section{Discussion}

In the current study working memory of children from elementary education was assessed through the Brown-Peterson task. The results showed that working memory performance improves gradually along the school grades and age. This result is consistent with studies showing late maturing of neural areas correlated with working memory and executive functions, such as frontal and prefrontal cortex14. In the present study, a significant working memory improvement was observed after transition from 1st to 2nd grade and from 5th to 6th grade. Although there was a continuous improvement from 2nd to 3rd to 4th grade, these differences were not significant. A possible correlation between working memory improvement and other variables which were not controlled for in this study, such as reading and writing development, should be investigated in the future studies. The progressive improvement in working memory performance was also found in a study with Canadian children with ages from 9 to 15 years15. Comparing the Canadian scores with the ones of Brazilian children for each age group, only small differences were found: 9 years (37.1 Canadians X 36.5 Brazilians), 10 years (38.2 X 40.5) and 11 years ( 40.3 X 37.6). The scores of Canadian teenagers with 15 years of age did not reach the level of adults which indicates that the development of working memory continues into adolescence. 
The interference effect on working memory, possibly through a suppression of verbal reverberation during the delay period, was evident on the decrease in performance observed in a similar way in all assessed grades. Considering that the Brown-Peterson task requires divided attention and working memory, the results of this study indicate that although children in higher grades improve in these skills, they suffer from the same interference effect as children in earlier grades.

Concerning the Brown-Peterson task applicability for the assessment of memory skills in children, the results showed a positive correlation with Digit Span, a widely recognized working memory measure. Other studies have also found correlation between the Brown-Peterson task and the Backward Digit task16 and factor analysis loaded on a factor of working memory and divided attention17.

In this study, the Brown-Peterson task revealed greater power to discriminate among the grades than the Digit Span. This may be due to the higher number of trials in the Brown-Peterson task resulting in a larger spectrum of total scores. Tasks such as the Brown-Peterson, with a constant number of stimuli and varying interference delay,

\section{References}

1. Baddeley AD, Hitch G. Working Memory. In: Bower GH, editor. The psychology of learning and motivation, v. 8. Londres: Academic Press; 1974. p. 47-90

2. Baddeley AD. Is Working Memory Still Working? European Psychologist. 2002;7(2):85-97.

3. Cowan N, Baddeley AD, Elliott EM, Norris J. List composition and the word length effect in immediate recall: A comparison of localist and globalist assumptions Psychonomic Bulletin \& Review. 2003;10(1):74-9.

4. Muller ST, Krawitz, A. Reconsidering the two-second decay hypothesis in verbal working memory. Journal of Mathematical Psychology. 2009;53(1):14-25.

5. Van Der Molen MJ, Van Luit JE, Jongmans MJ, Van Der Molen NMW. Verbal working memory in children with mild intellectual disabilities. Journal of Intellectual Disability Research. 2007;51:162-9.

6. Gindri G, Keske-Soares M, Mota HB. Memória de trabalho, consciência fonológica e hipótese de escrita. PróFono Revista de Atualização Científica. 2007 JulSet;19(3):313-22. offer a better assessment of working memory information loss rate. On the other hand, one of the limitations of the Brown-Peterson task is the type of task performed during the interference, since fluency on counting can vary among children according to individual arithmetic skills. In young children, whose such skills are limited, counting can implicate in increasing distraction of to-beremembered stimuli compared to children with a fluent counting. A study with university students did not show any association of arithmetical ability with recall on the Brown-Petersen task, however, results from other studies are divergent4, 18. Future studies should bring more conclusions related to this issue.

\section{Conclusion}

This study aimed to evaluate working memory skills in children from 1st to 6th grade of elementary school. The results showed improvement in such skills along the grades and indicated that the Brown-Peterson task is an adequate task for complex attention and working memory assessment in children.
7. Gindri G, Keske-Soares M, Mota HB. Comparação do desempenho de crianças pré-escolares e de primeira série em tarefas envolvendo a memória de trabalho. Revista da Sociedade Brasileira de Fonoaudiologia. 2005 OutDez;10(4):201-6.

8. Ziegler J, Goswami U. Reading acquisition, developmental dyslexia, and skilled reading across languages: a psycholinguistic grain size theory. Psychological Bulletin. 2005;131(1):3-29.

9. Wechsler D, Figueredo VLM. WISC-III: escala de inteligência Wechsler para crianças - adaptação brasileira da $3^{\mathrm{a}}$ edição. São Paulo: Casa do Psicólogo; 2002.

10. Kessler TM. Estudo da memória operacional em préescolares [dissertação]. Mestrado em Distúrbios da Comunicação Humana: Universidade Federal de Santa Maria; 1997.

11. Strauss E, Sherman EMS, Spreen O. A compendium of Neuropsychological Tests. 3a ed. New York: Oxford University Press; 2006.

12. Folden D, Stuss DT, Craik FIM. Age differences in performance on two versions of the Brown-Peterson Task. Aging, Neuropsychology and Cognition. 2000;7(4):24559. 
13. Hamdan AC, Bueno OFA. Relações entre controle executivo e memória episódica verbal no comprometimento cognitivo leve e na demência tipo Alzheimer. Estud. psicol. (Natal). 2005 Jan-Apr;10(1):637.

14. Gogtay N, Giedd JN, Lusk L, Hayashi KM, Greenstein D, Vaituzis AC, et al. Dynamic mapping of human cortical development during childhood through early adulthood. Proc Natl Acad Sci U S A. 2004;101(21):8174-9.

15. Paniak CE, Millar HB, Murphy D, Keizer J. A consonant trigrams test for children: development and norms. The Clinical Neuropsychologist. 1997;11:198-200.
16. Anil AE, Kivircik BB, Batur S, Kabakci E, Kitis A, Guvent E, et al. The Turkish version of the auditory consonant trigram test as a measure of working memory: a normative study. Clinical Neuropsychologist. 2003;17(2):159-69.

17. Mertens VB, Gagnon M, Coulombe D, Messier C. Exploratory factor analysis of neuropsychological tests and their relationship to the Brown-Peterson Task. Archives of Clinical Neuropsychology. 2006;21:733-9.

18. Greene RL. The influence of experimental design: the example of the Brown-Peterson paradigm. Canadian Journal of Experimental Psychology. 1996;50(2):240-2. 